Butler, M. \& KNight, B. C. J. G. (1960). J. gen. Microbiol. 22, 483-491

\title{
Steroid Growth Requirements and Steroid Growth Inhibitors of Mycoplasma
}

\author{
By M. BUTLER ANd B. C. J. G. KNIGHT \\ Department of Microbiology, University of Reading
}

\begin{abstract}
SUMMARY: Mycoplasma laidlareii strain A did not grow significantly and sometimes died in a peptone + yeast extract (PY) medium; good growth was obtained when $1 \%$ serum or $1 \%$ bovine plasma albumin was added. The addition of cholesterol and some other steroids (at $20 \mu \mathrm{g}$. $/ \mathrm{ml}$.) to the basal PY medium gave some growth although less than that given by adding serum or albumin. Certain other steroids (e.g. $\Delta^{\mathbf{1}, 4}$ and $\Delta^{1,4,6}$-cholesten-3-one) were potent inhibitors of cholesterol-promoted growth at onetenth the cholesterol concentration. One of these steroids at $2 \mu \mathrm{g} . / \mathrm{ml}$. inhibited the growth which was obtained in PY + albumin medium; this inhibition was annulled by $200 \mu \mathrm{g}$. cholesterol $/ \mathrm{ml}$. Two of the inhibitory steroids at $c .300 \mu \mathrm{g} . / \mathrm{ml}$. inhibited the growth of $M$. laidlawii strains A and B, M. mycoides var. capri and $M$. bovigenitalium in a rich serum-containing medium. The inhibitory effects of one of these steroids was greatly diminished when it was added after growth had begun.
\end{abstract}

Cholesterol or related steroids have been found to be required for the growth of parasitic Mycoplasma sp. (Edward \& Fitzgerald, 1951; Smith, Lecee \& Lynn, 1954; Rodwell, 1956; Smith \& Lynn, 1958). No evidence about steroid requirements for the growth of saprophytic Mycoplasma has hitherto been reported (Edward \& Freundt, 1956). It was our object to see whether the saprophytic species required steroids and if so to examine the specificity of the requirement. In the course of this work it was found that certain steroids showed growth-inhibitory effects which could be annulled by other steroids.

\section{METHODS}

Organisms. Mycoplasma laidlawii strain A (PG 8), M. laidlawii strain B (PG 9) and M. bovigenitalium (PG 12) were kindly given by Dr D. G. ff. Edward (The Wellcome Research Laboratories, Beckenham, Kent). M. mycoides var. capri and the stable L-phase of Streptobacillus moniliformis were kindly given by Dr E. Klieneberger-Nobel (The Lister Institute of Preventive Medicine, London).

Culture media. Two basal media were used: (1) a modified Edward medium (Butler \& Knight, 1960b); (2) a peptone + yeast extract (PY) medium composed of $(\%, w / v)$; peptone (Evans), 1.4; yeast extract (Oxoid), 0.5; sodium chloride, 0.5 ; potassium phosphate $\left(\mathrm{K}_{2} \mathrm{HPO}_{4}\right), 0 \cdot 35$. This medium was brought to $\mathrm{pH} 8$ with $\mathrm{N}-\mathrm{NaOH}$. Stock solutions of peptone, sodium chloride and potassium phosphate were sterilized at $121^{\circ}$ for $20 \mathrm{~min}$. Yeast extract solution was sterilized by passage through a Seitz filter.

In experiments in which growth was measured by acid production the two media were prepared to contain $0.75 \%(w / v)$ glucose and adjusted to $\mathrm{pH} \mathrm{8.4.}$ 
A stock solution of glucose $(37 \%, w / v)$ was sterilized by suction through a sintered-glass bacterial filter.

Steroids. The following steroids were used: cholesterol (British Drug Houses Ltd.); cholestan-3-one, $\Delta^{\mathbf{1}}$-cholesten-3-one, $\Delta^{\mathbf{4}}$-cholesten-3-one, $\Delta^{\mathbf{1}, 4}$-cholesten3-one, $\Delta^{1,4,6}$-cholesten-3-one, progesterone, deoxycorticosterone 21-acetate, corticosterone, 17-hydroxy corticosterone, and cortisone 21-acetate (kindly given by Dr R. M. Evans, Glaxo Laboratories Ltd., Greenford, Middlesex). Solutions of the steroids were prepared in ethanol, warmed when necessary to c. $60^{\circ}$, and were injected by syringe into the medium before inoculation.

Conditions of cultivation. Cultures for inocula were grown as described previously (Butler \& Knight, 1960a). The inoculum for experiments in Edward medium was from a $24 \mathrm{hr}$. culture. The inoculum for experiments in PY medium was obtained from a washed suspension of organisms (Butler \& Knight, $1960 a$ ). Some experiments were made in $\perp$-tubes (van-Heyningen $\&$ Gladstone, 1953) which were rocked in a water bath at $37^{\circ}$. In other experiments 6 in. $\times \frac{5}{8}$ in. test tubes were used; these were incubated vertically in air at $37^{\circ}$ without agitation.

Measurement of growth. The extent of growth was measured by the colony count method of Miles \& Misra (1938) as adapted for Mycoplasma (Butler \& Knight, 1956, 1960 a) and by titrating the acid formed by the organisms during growth in the glucose-containing media (Razin \& Knight, 1960a).

\section{RESULTS}

Growth in PY medium containing serum, albumin or steroids

Mycoplasma laidlawii strain A did not grow significantly, and sometimes died, in the PY medium alone, but grew when $1 \%(v / v)$ serum or $1 \%(w / v)$ crystallized bovine plasma albumin (Armour Laboratories, Eastbourne, England) was added to the medium; this growth was about the same as in the rich Edward medium (Fig. 1).

The addition of cholesterol to PY medium enabled some growth of Mycoplasma laidlawii strain A. The optimal concentration was $c .50 \mu$ g. cholesterol/ ml., but this growth was somewhat less than in Edward medium (Fig. 2). M. laidlawii strain B responded to cholesterol in PY medium in a similar way.

The specificity of the steroid requirement. Other related steroids were tested for growth-promoting activity towards Mycoplasma laidlawii strain A in PY medium. Cholestan-3-one, $\Delta^{\mathbf{1}}$-cholesten-3-one and $\Delta^{\mathbf{4}}$-cholesten-3-one at $20 \mu \mathrm{g} . / \mathrm{ml}$. all had nearly the same growth-promoting effect as $20 \mu \mathrm{g}$. cholesterol/ ml. (Fig. 3); $\Delta^{1,4}$-cholesten-3-one and $\Delta^{1,4,6}$-cholesten-3-one had no growthpromoting effect at 20 or $200 \mu \mathrm{g}$. $/ \mathrm{ml}$. (Fig. 3). Progesterone, deoxycorticosterone 21-acetate, corticosterone, 17-hydroxycorticosterone and cortisone had no growth-promoting effect at $50 \mu \mathrm{g} . / \mathrm{ml}$. 


\section{Inhibitory effects of certain steroids}

Inhibitory effects in PY medium. $\Delta^{1,4}$-Cholesten-3-one and $\Delta^{1,4,6}$-cholesten3-one showed inhibitory effects on cholesterol-promoted growth of Mycoplasma laidlawii strain A in PY medium; Table 1 illustrates this for $\Delta^{\mathbf{1 , 4}}$-cholesten-3one; very similar values were obtained with $\Delta^{\mathbf{1 . 4}, 6}$-cholesten-3-one. These inhibitors were relatively potent: there was complete inhibition of growth promoted by cholesterol by one-tenth of its weight of analogue and partial inhibition by one-hundredth.

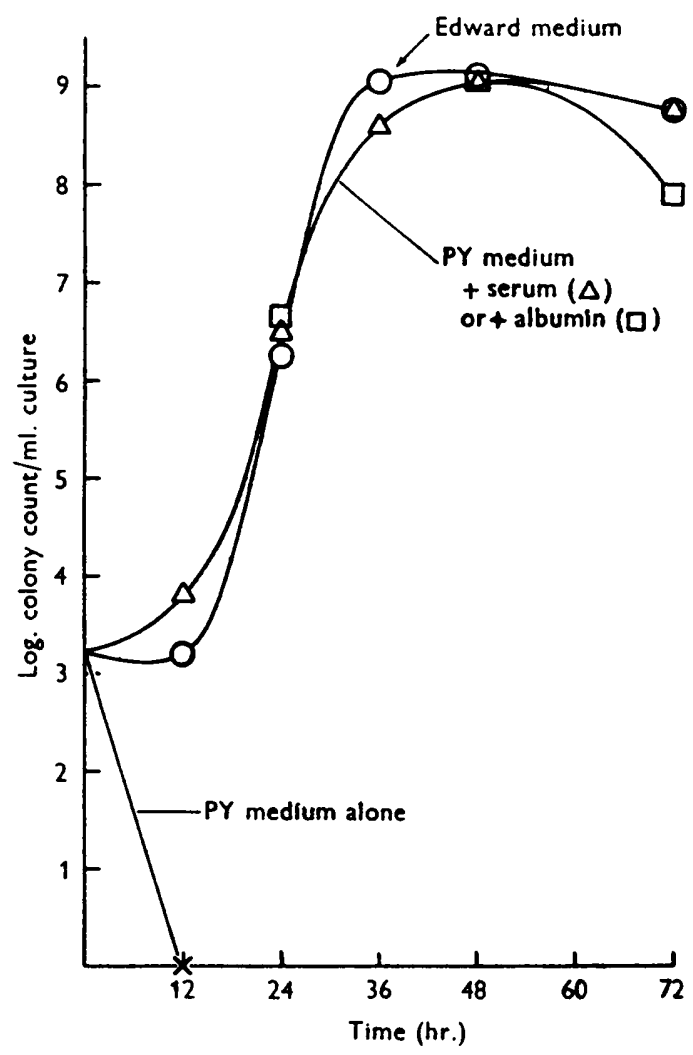

Fig. 1. The growth of Mycoplasma laidlawii strain A in PY medium in the presence of serum or crystallized bovine plasma albumin. PY medium alone, $x \times$; PY medium $+1 \%$ $(v / v)$ serum, $\Delta \triangle$; PY medium $+1 \%(w / v)$ albumin, $\square \square$; Edward medium, $O O$. Cultures in $\perp$-tubes; $10 \mathrm{ml}$. medium inoculated with $0.1 \mathrm{ml} .10^{-3}$ dilution of washed suspension.

Some other steroids were tested for inhibition of the cholesterol-promoted growth of Mycoplasma laidlawii strain A in PY medium. Progesterone and deoxycorticosterone 21-acetate completely inhibited cholesterol-promoted growth at a 1:1 weight ratio (other ratios not tested). Corticosterone, 17hydroxy corticosterone and cortisone 21 -acetate slightly delayed growth at a $1: 1$ weight ratio. 
Inhibitory effects in PY + albumin medium. The growth of Mycoplasma laidlawii strain A in PY medium containing $1 \%(w / v)$ crystallized bovine plasma albumin was completely inhibited by $\Delta^{1,4}$ cholesten-3-one at $2 \mu \mathrm{g} . / \mathrm{ml}$. The addition of 200 , but not $20, \mu \mathrm{g}$. cholesterol $/ \mathrm{ml}$. overcame this inhibition (Table 2).

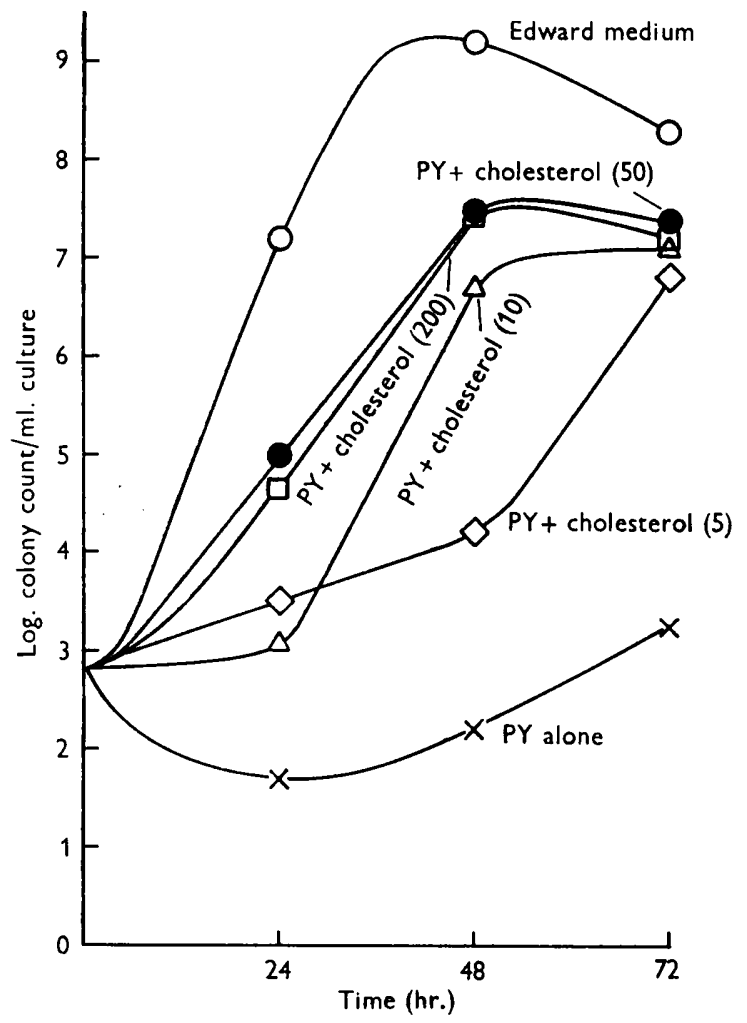

Fig. 2. The growth of Mycoplasma laidlawii strain A in PY medium in the presence of different amounts of cholesterol $(\mu \mathrm{g} . / \mathrm{ml}$.) as shown on the figure. Cultures in 1 -tubes; $10 \mathrm{ml}$. medium inoculated with $0 \cdot 1 \mathrm{ml} \cdot 1^{-3}$ dilution of washed suspension.

Table 1. The growth of Mycoplasma laidlawii strain $A$ in PY medium containing cholesterol and $\Delta^{1,4}$-cholesten-3-one

Volumes of $10 \mathrm{ml}$. medium in 1 -tubes were inoculated with $0.1 \mathrm{ml} \cdot 10^{-3}$ dilution of washed suspension. Incubation was at $37^{\circ}$; samples for counting were taken after $48 \mathrm{hr}$.

\begin{tabular}{|c|c|c|}
\hline \multirow{2}{*}{$\begin{array}{c}\Delta^{1,4 \text {-Cholesten-3-one }} \\
(\mu \mathrm{g} . / \mathrm{ml} .)\end{array}$} & \multicolumn{2}{|c|}{ Cholesterol ( $\mu \mathrm{g} . / \mathrm{ml})}$. \\
\hline & $\begin{array}{c}20 \\
\text { Log. }\end{array}$ & $\begin{array}{c}200 \\
\mathrm{int} / \mathrm{ml}\end{array}$ \\
\hline o & $6 \cdot 8$ & $7 \cdot 5$ \\
\hline 0.02 & $7 \cdot 1$ & $7 \cdot 3$ \\
\hline $0 \cdot 2$ & $2 \cdot 9$ & $7 \cdot 5$ \\
\hline $\mathbf{2 \cdot 0}$ & $\mathbf{0}$ & $6 \cdot 1$ \\
\hline $20 \cdot 0$ & $\mathbf{0}$ & 0 \\
\hline
\end{tabular}


Inhibitory effects in Edward medium. The growth of Mycoplasma laidlawii strain $A$ in the complex Edward medium was completely inhibited by $\Delta^{\mathbf{1 , 4}}$. cholesten-3-one and $\Delta^{1,4,6}$-cholesten-3-one at 200 and $300 \mu \mathrm{g}$. ml., respectively (Table 3). The larger doses of inhibitors required in Edward medium were presumably related to its cholesterol content. Viable counts showed that these two steroids did not kill the organisms even at the highest concentrations tested.

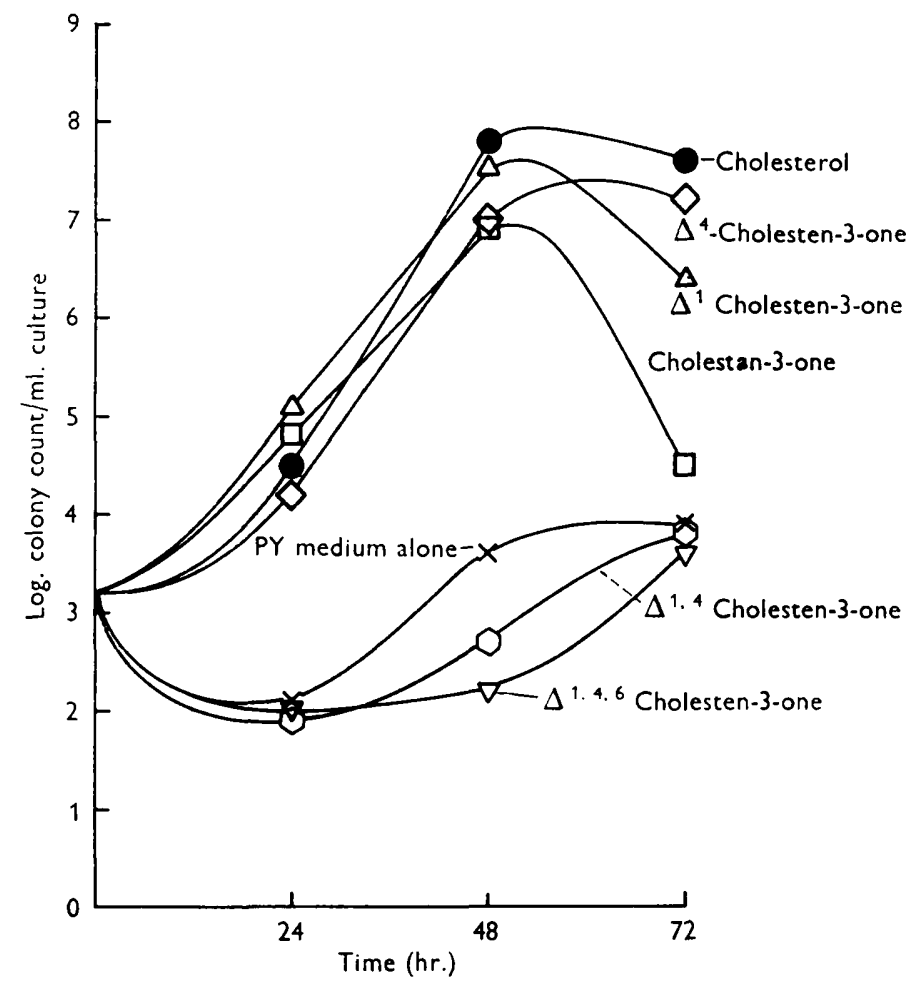

Fig. 3. The growth of Mycoplasma laidlawii strain A in PY medium in the presence of various steroids (shown on the figure) at $20 \mu \mathrm{g} . / \mathrm{ml}$. Cultures in $\perp$-tubes; $10 \mathrm{ml}$. medium inoculated with $0 \cdot 1 \mathrm{ml} .10^{-3}$ dilution of washed suspension.

Table 2. The effect of adding cholesterol and $\Delta^{1,4}$-cholesten-3-one on the growth of Mycoplasma laidlawii strain $\boldsymbol{A}$ in $\boldsymbol{P Y}$ medium containing $1 \%(w / v)$ crystallized bovine plasma albumin

Organisms grown in $\perp$-tubes containing $10 \mathrm{ml}$. medium/tube and inoculated with $0 \cdot 1 \mathrm{ml}$. $10^{-3}$ dilution of washed suspension. Incubation at $37^{\circ}$. Samples taken after $72 \mathrm{hr}$.

Medium (quantities in $\mu \mathrm{g} . / \mathrm{ml}$ )

PY medium + albumin (PYA)

PYA +20 cholesterol

PYA +200 cholesterol

PYA + 0.2 $\Delta^{1,4}$-cholesten-3-one

PYA + 2.0 $\Delta^{1,4}$-cholesten-3-one

PYA + 2.0 $\Delta^{1,4}$-cholesten-3-one +20 cholesterol

PYA $+2 \cdot 0 \Delta^{1.4}$-cholesten-3-one +200 cholesterol
Acid production equiv. 0.01 N-NaOH (ml./10 ml. culture) 
Cholesterol, $\Delta^{1}$-cholesten-3-one or $\Delta^{4}$-cholesten-3-one, at $500 \mu \mathrm{g} . / \mathrm{ml}$. were slightly inhibitory.

The inhibitory effect of $\Delta^{1,4}$-cholesten-3-one towards growth of Mycoplasma laidlawii strain $\mathbf{A}$ in Edward medium was slightly diminished by adding high concentrations of cholesterol. The inhibitory effect of $\Delta^{\mathbf{1 , 4 , 6} \text {-cholesten-3-one }}$

Table 3. The effect of various steroids on the growth of Mycoplasma laidlawii strain $A$ in Edward medium

The cultures were in test tubes and incubated $\left(37^{\circ}\right)$ vertically without agitation; $10 \mathrm{ml}$. medium. Inoculation with $0.1 \mathrm{ml}$. dilution of $24 \mathrm{hr}$. culture. Samples taken after $96 \mathrm{hr}$.

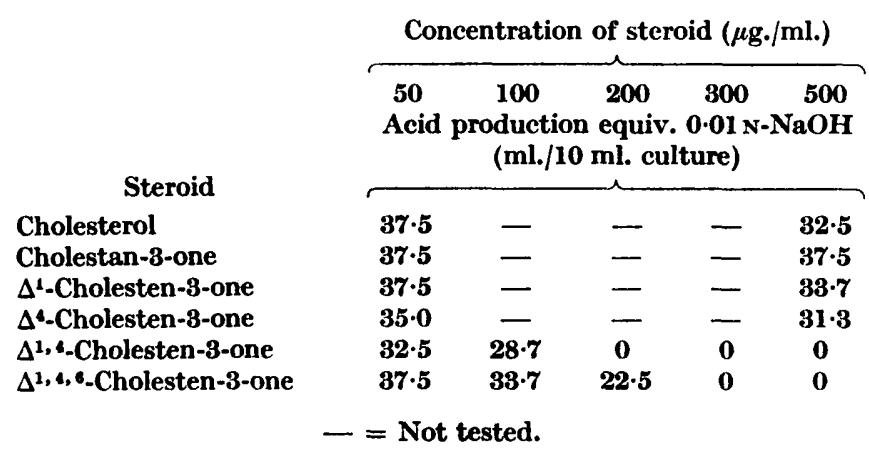

Table 4. The effect of cholesterol on the growth of Mycoplasma laidlawii strain A in Edroard medium containing inhibitory concentrations of $\Delta^{1,4}$-cholesten-3one or $\Delta^{1,4,6}$-cholesten-3-one

The cultures were in test tubes incubated $\left(37^{\circ}\right)$ vertically without agitation; $10 \mathrm{ml}$. medium; inoculation with $0 \cdot 1 \mathrm{ml} .10^{-3}$ dilution of a $24 \mathrm{hr}$. culture. Samples taken after $96 \mathrm{hr}$.

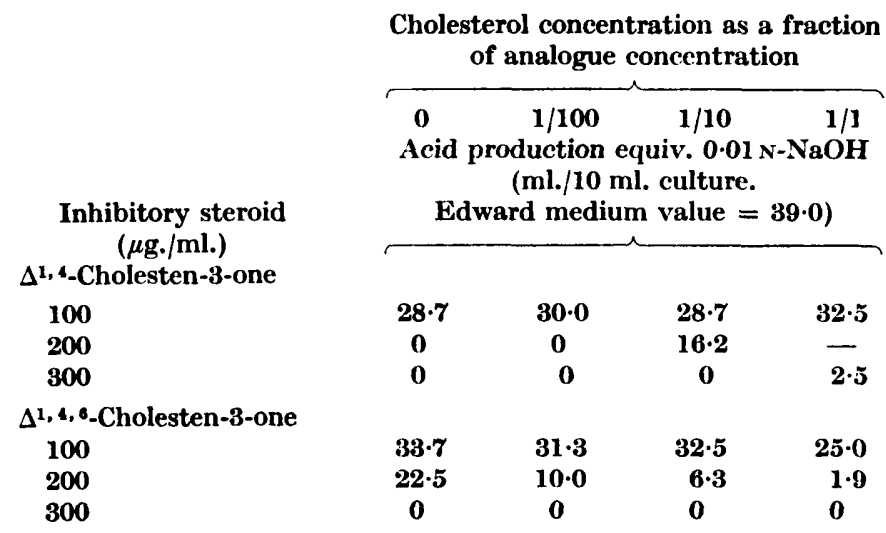

was slightly increased in the presence of added cholesterol (Table 4). Edward \& Fitzgerald (1951) noted that a balance of steroid, a lipid and albumin was required for growth promotion of parasitic strains.

Inhibitory effects on other organisms in Edward medium. $\Delta^{1,4}$-Cholesten-3one at $400 \mu \mathrm{g} . / \mathrm{ml}$. inhibited the growth in Edward medium of Mycoplasma laidlawii strain B, M. mycoides var. capri and $M$. bovigenitalium. Slight inhibitory effects were observed with cholesterol, cholestan-3-one or $\Delta^{\mathbf{4}}$ - 
cholesten-3-one at $500 \mu \mathrm{g} . / \mathrm{ml}$. The growth of the stable L-phase of Streptobacillus moniliformis in Edward medium was inhibited by low concentrations ( $5 \mu \mathrm{g} . / \mathrm{ml}$.) of cholesterol, cholestan-3-one, $\Delta^{4}$-cholesten-3-one or $\Delta^{1.4}$-cholesten3-one (Table 5).

Table 5. The effect of some steroids on the growth of the stable L-phase of Streptobacillus moniliformis in Edward medium

The cultures were in test tubes incubated $\left(37^{\circ}\right)$ vertically without agitation; $10 \mathrm{ml}$. medium; inoculated with $0.1 \mathrm{ml}$. of a $24 \mathrm{hr}$. culture. Samples taken after $48 \mathrm{hr}$.

\begin{tabular}{|c|c|}
\hline $\begin{array}{l}\text { Edward medium + steroid } \\
\qquad(\mu \mathrm{g} . / \mathrm{ml} .)\end{array}$ & $\begin{array}{c}\text { Acid production equiv } \\
0.01 \mathrm{~N}-\mathrm{NaOH} \\
(\mathrm{ml} / \mathrm{10} \mathrm{ml} \text {. culture })\end{array}$ \\
\hline No steroid & $18 \cdot 8$ \\
\hline \multicolumn{2}{|l|}{ Cholesterol } \\
\hline j & $\mathbf{2 \cdot 5}$ \\
\hline $\mathbf{5 0}$ & $\mathbf{2 \cdot 5}$ \\
\hline \multicolumn{2}{|l|}{ Cholestan-3-one } \\
\hline $\mathbf{5}$ & $8 \cdot 8$ \\
\hline $\mathbf{5 0}$ & $\mathbf{0}$ \\
\hline \multicolumn{2}{|l|}{$\Delta^{4}$-Cholesten-3-one } \\
\hline 5 & $3 \cdot 8$ \\
\hline $\mathbf{5 0}$ & $\mathbf{0}$ \\
\hline \multicolumn{2}{|l|}{$\Delta^{1,4}-$ Cholesten-3-one } \\
\hline $\mathbf{5}$ & $\mathbf{3 \cdot 8}$ \\
\hline $\mathbf{5 0}$ & $\mathbf{0}$ \\
\hline
\end{tabular}

Table 6. The effect of time of adding $\Delta^{1,4}$-cholesten-3-one on the growth of Mycoplasma laidlawii strain $A$ and M. mycoides var. capri in Edroard medium

The steroid was added $(a)$ to the medium before inoculation; $(b)$ to the culture at the end of the lag period. The cultures were in test tubes incubated $\left(37^{\circ}\right)$ vertically without agitation; $10 \mathrm{ml}$. medium inoculated with $0.1 \mathrm{ml}$. of a $24 \mathrm{hr}$. culture.

\begin{tabular}{|c|c|c|}
\hline & \multicolumn{2}{|c|}{$\begin{array}{c}\text { Acid production equiv. } \\
0 \cdot 01 \mathrm{~N}-\mathrm{NaOH} \\
\text { (ml./10 ml. culture) }\end{array}$} \\
\hline & $\begin{array}{l}\text { M. Laidlawii } \\
\text { strain } \mathbf{A}^{*}\end{array}$ & $\begin{array}{l}\text { M. mycoides } \\
\text { var. caprit }\end{array}$ \\
\hline Edward medium & 23 & 48 \\
\hline $\begin{array}{l}\text { Edward medium }+ \text { steroid } \\
\text { added before inoculation }\end{array}$ & 11 & $2 \pi$ \\
\hline $\begin{array}{l}\text { Edward medium + steroid } \\
\text { added at the end of the } \\
\text { lag period }(9 \mathrm{hr} .)\end{array}$ & 19 & 46 \\
\hline
\end{tabular}

The effect of time of addition of steroid. All the foregoing results were obtained by adding the steroids to the media before inoculating them. The inhibitory effect of $\Delta^{1,4}$-cholesten-3-one towards Mycoplasma laidlawii strain $\mathbf{A}$ and $M$. mycoides var. capri was also tested by adding it to cultures in Edward medium, when the organisms were at the end of the lag period. The inhibitory effect was then diminished (Table 6). Similarly, this steroid did not inhibit the growth of $M$. laidlawii strain A in PY medium when added 24 or $30 \mathrm{hr}$. after inoculation. 


\section{DISCUSSION}

Laidlaw \& Elford (1936), in their classic work on saprophytic Mycoplasma, found that the best medium for growing their strains sewage $\mathbf{A}, \mathbf{B}$ and $\mathbf{C}$ was the medium described by Fildes (1920) for growing haemophilic bacteria. This medium contains Hartley's tryptic digest broth made from horse muscle, enriched with a peptic digest of red blood cells, and would contain considerable amounts of cholesterol. Our observations show that cholesterol and some related steroids promoted the growth of Mycoplasma laidlawii strain $\mathbf{A}$ in a peptone + yeast extract (PY) medium. The experiments with cholesterol analogues, in which some replaced cholesterol and others inhibited cholesterolpromoted growth, indicate a certain degree of specificity in the steroid effect. We also found that growth occurred in PY medium in the presence of albumin without added cholesterol. Razin \& Knight (1960 a) obtained some growth of M. laidlawii strain A in a partially-defined medium presumably free from cholesterol. Growth in that medium was not improved by adding cholesterol, but growth under their conditions may have been limited by the absence of other growth factors (see Razin \& Knight, 1960a). On present evidence it seems possible that the growth promotion by cholesterol reported now may be due to its playing a detoxicating role, e.g. versus traces of fatty acids present in the basal PY medium (compare Pollock, 1949; Kodicek, 1949; see Razin \& Knight, 1960a).

Our observations that cholestan-3-one, $\Delta^{1}$-cholesten-3-one or $\Delta^{4}$-cholesten3-one replaced cholesterol in growth-promotion contrast with the findings of Smith \& Lynn (1958) that the 3-hydroxy group of cholesterol was essential for its growth-promoting activity for human strains of Mycoplasma.

The growth-inhibitory action of all the steroids tested against the stable L-phase of Streptobacillus moniliformis recalls the observations by Edward (1953) that cholesterol slightly inhibited the growth of the L-phase of a Proteus sp.

The inhibition of cholesterol-promoted growth of Mycoplasma laidlawii strain A in PY medium by other steroids and the annulment of steroid growthinhibition in PY medium + albumin by adding cholesterol is of interest, because there are only a few reports of such effects. Conner \& Nakatani (1958) found that inhibition of the growth of Tetrahymena pyriformis by deoxycorticosterone, progesterone or cortisone was annulled by stigmasterol; see also Conner (1959). Lister, Stone \& Hechter (1958) examined the effects of various steroids on the growth of Neurospora crassa and found that deoxycorticosterone and some related sex hormones inhibited growth; some other steroids, e.g. ergosterol and cholesterol, diminished this inhibition.

A grant from the Agricultural Research Council in support of this work is gratefully acknowledged. 


\section{REFERENCES}

Butler, M. \& KNight, B. C. J. G. (1956). Growth curves of strains of pleuropneumonia-like organisms. J. gen. Microbiol. 14, vi.

Butler, M. \& KNight, B. C. J. G. (1960a). The survival of washed suspensions of Mycoplasma. J. gen. Microbiol. 22, 470.

Butler, M. \& KNight, B. C. J. G. $(\mathbf{1 9 6 0 b})$. The measurement of growth of Mycoplasma in liquid media. J. gen. Microbiol. 22, 478.

ConNer, R. L. (1959). Inhibition of growth of Tetrahymena piriformis by certain steroids. J. gen. Microbiol. 21, 180.

ConNer, R. L. \& NAKatani, M. (1958). Stigmasterol antagonism of certain growth inhibitors of Tetrahymena pyriformis. Arch. Biochem. Biophys. 74, 175.

EDWARD, D. G. FF. (1953). A difference in growth requirements between bacteria in the L-phase and organisms of the pleuropneumonia group. J.gen. Microbiol. 8, 256.

Edward, D. G. FF. \& Fitzgerald, W. A. (1951). Cholesterol in the growth of organisms of the pleuropneumonia group. J. gen. Microbiol. 5, 576.

EDWARD, D. G. FF. \& Freundt, E. A. (1956). A classification and nomenclature of organisms in the pleuropneumonia group. J. gen. Microbiol. 14, 197.

Fildes, P. (1920). A new medium for the growth of B. influenzae. Brit. J. exp. Path. $1,129$.

Heyningen, W. E. van \& Gladstone, G. P. (1953). The neurotoxin of Shigella shigae. Brit. J. exp. Path. 34, 221.

KoDICEK, E. (1949). The effect of unsaturated fatty acids on Gram-positive bacteria. Symp. Soc. exp. Biol. 3, 217.

Laidlaw, P. P. \& Elford, W. J. (1936). A new group of filterable organisms. Proc. roy. Soc. B, 120, 292.

Lister, G., Stone, D. \& Hechter, O. (1958). The effects of deoxycorticosterone and other steroids on Neurospora crassa. Arch. Biochem. Biophys. 75, 196.

Miles, A. A. \& Mrsra, S. S. (1938). The estimation of the bactericidal power of the blood. J. Hyg., Camb. 38, 732.

Pollock, M. R. (1949). The effect of long-chain fatty acids on the growth of Haemophilus pertussis and other organisms. Symp. Soc. exp. Biol. 3, 193.

Razin, S. \& Knight, B. C. J. G. (1960a). A partially defined medium for the growth of Mycoplasma organisms. J. gen. Microbiol. 22, 492.

Rodwelr, A. W. (1956). The role of serum in the nutrition of Asterococcus mycoides. Aust. J. biol. Sci. 9, 105.

Smith, P. F., Lecce, J. G. \& LyNN, R. J. (1954). A lipoprotein as a growth factor for certain pleuropneumonia-like organisms. J. Bact. 68, 627 .

Smith, P. F. \& LYNN, R. J. (1958). Lipid requirements for the growth of pleuropneumonia-like organisms. J. Bact. 76, 264.

(Received 22 September 1959) 